\title{
PENERAPAN INKUIRI DALAM MENINGKATKAN \\ KETERAMPILAN DAN PENGETAHUAN SISWA SMPN 18 MALANG
}

\author{
ANNA JARROTUL KHOIRIYAH \\ SMPN 18 Malang \\ Email : anajkoir@gmail.com
}

\begin{abstract}
ABSTRAK
Tujuan dari best practice ini adalah untuk meningkatkan keterampilan dan pengetahuan siswa pada pembelajaran IPA dengan model pembelajran inkuiri. Tulisan ini menggunakan metode best practice. Data keterampilan diproleh dari rata-rata skor kegiatan praktikum dan pengetahuan diperoleh dari rata-rata hasil belajar. Temuan pada best practice ini adalah ketika siswa mendesain percobaan sendiri, melakukan praktik dari hasil desain, menemukan sendiri konsep yang dipelajari melalui tahapan inkuiri, siswa menjadi lebih terampil dan lebih paham. Bagian penting lain dari penelitian ini adalah pentingnya guru memiliki keterampilan membuka pembelajaran, mendesain pembelajaran, dan memfasilitasi siswa belajar. Keterampilan membuka pembelajaran yang penting adalah dengan memberikan stimulus yang berupa gambar, video, fenomena, dan pertanyaan-pertanyaan yang dapat memotivasi dan membangkitkan tingkat berpikir siswa. Hasil best practice menunjukkan, terdapat peningkatan keterampilan sebesar 32\% untuk skor, $108 \%$ untuk ketuntasan dan pengetahuan sebesar $13 \%$ untuk skor, $52 \%$ untuk ketuntasan.
\end{abstract}

Kata kunci: Penerapan inkuiri, keterampilan, pengetahuan

\section{ABSTRACT}

The purpose of this research is to improve the knowledge and skills of students in science learning with the inquiry learning model. This paper uses the best practice method. Skill's data is obtained from the average practicum activities score and knowledge is obtained from the average of learning outcomes. The findings in this research are when the students try to design and find their own concepts learned through the inquiry stage, the students become more skilled and more understanding. Another important part of this research is teachers must have the skills to open lessons, design lessons and facilitate students in learning. An important skill to open learning is to provide a stimulus in the form of pictures, videos, phenomena, and questions that can motivate and raise students' thinking levels. The results showed there is an improvement of skills by $32 \%$ for scores, $108 \%$ for completeness and knowledge of $13 \%$ for scores and $52 \%$ for completeness.

Key word: Implementation of inquiry, knowledge, skills

\section{PENDAHULUAN}

Keterampilan dan pengetahuan penting dimiliki siswa untuk bekal dalam kehidupan sehari-hari dan dimasa yang akan datang. Tantangan ke depan yang akan dihadapi semakin rumit dan membutuhkan keterampilan dan pengetahuan yang tinggi. Life skill pada abad 21 meliputi thinking kecakapan berpikir yang mencakup kemampuan memecahkan masalah, acting kecakapan bertindak yang mencakup berkolaborasi, dan living kecakapan menjalani kehidupan yang membutuhkan keterampilan (Greenstein, 2012).

Berdasar data di lapangan rata-rata skor keterampilan sebesar 72 dan ketuntasan sebesar $48 \%$ sedangkan rata-rata skor pengetahuan sebesar 75 dan ketuntasan sebesar $64 \%$. Berdasar angket yang diberikan, siswa menyatakan bahwa sebagian besar tidak paham dengan materi yang diberikan dan tidak terbiasa dengan kegiatan praktikum. Berdasar observasi saat pembelajaran berlangsung hanya siswa tertentu yang aktif, siswa cenderung bekerja secara individu, siswa kurang percaya diri saat bertanya, menjawab, dan vpresentasi (lebih mengandalkan teks), dan siswa terlihat ragu-ragu saat melakukan praktikum. 
Keterampilan diharapkan dapat meningkat melalui pembiasaan. Pengetahuan diharapkan dapat meningkat apabila siswa paham dengan apa yang dipelajari sehingga dapat meningkatkan hasil belajar. Berdasarkan Permendikbud no 53 (2015) Penilaian pengetahuan adalah penilaian yang dilakukan untuk mengetahui penguasaan siswa yang meliputi pengetahuan faktual, konseptual, maupun prosedural serta kecakapan berpikir tingkat rendah hingga tinggi. Berdasarkan penelitian yang dilakukan Wairata (2021) dan Dewi (2021) menyatakan bahwa inkuri dapat meningkatkan ketuntasan dan hasil belajar siswa.

Langkah-langkah pada pembelajaran inkuiri adalah sebagai berikut (1) identifikasi dan penetapan ruang lingkup masalah, (2) merumuskan hipotesis, (3) merancang percobaan (4) mengumpulkan dan interpretasi data, (5) membuat kesimpulan (Joyce, 2000). Langkah pada pembelajaran inkuiri ini diharapkan dapat memfasilitasi masalah yang terjadi. Berdasarkan penelitian yang dilakukan Nurussaniah, dkk. (2017) dan Suansah (2015) menyimpulkan bahwa pembelajaran inkuiri mampu meningkatkan keterampilan proses sains. Hal senada pada penelitian yang dilakukan Sen, dkk. (2015), Sen \& Vekli (2016) dengan kesimpulan bahwa pembelajaran inkuiri dapat meningkatkan keterampilan siswa. Pembelajaran inkuiri diharapkan dapat meningkatkan keterampilan dan pengetahuan siswa.

Tujuan dari best practice adalah untuk meningkatkan keterampilan dan pengetahuan siswa pada pembelajaran IPA dengan penerapan model pembelajran inkuiri. Rumusan masalah adalah bagaimana penerapan pembelajaran inkuri mampu meningkatkan keterampilan dan pengetahuan siswa pada pembelajaran IPA.

\section{METODE PELAKSANAAN}

Metode menggunakan pendekatan kualitatif dan kuantitatif. Instrumen berupa lembar observasi, lembar kerja siswa (LKS), dan ulangan harian (UH). Data keterampilan diperoleh dari rata-rata skor kegiatan praktikum (LKS) dan pengetahuan diperoleh dari rata-rata hasil belajar (UH). Data kualitatif pada penerapan pembelajaran inkuri diperoleh dari observasi saat pembelajaran berlangsung oleh observer. Subyek adalah siswa kelas VII SMPN 18 Malang, pada pembelajaran IPA.

\section{HASIL DAN PEMBAHASAN}

\section{Hasil}

Skor keterampilan meningkat sebesar $17 \%$ dan ketuntasan meningkat $96 \%$ di sikuls 1 dan meningkat $13 \%$ dan $6 \%$ di siklus 2 . Skor hasil belajar meningkat $11 \%$ dan ketuntasan meningkat 33\% disiklus 1 dan meningkat 2\% dan 14\% di siklus 2. Data keterampilan dijelaskan pada tabel 1 dan gambar 1 dan data Hasil belajar dijelaskan pada tabel 2 dan gambar 2.

Tabel 1. Rata-rata skor dan ketuntasan pada keterampilan

\begin{tabular}{lcccc}
\hline & \multirow{2}{*}{ Skor } & Ketuntasan & \multicolumn{2}{c}{ Peningkatan } \\
\cline { 4 - 5 } & & & Skor & Ketuntasan \\
\hline Data observasi & 72,36 & $48 \%$ & & \\
\hline Siklus 1 & 84,94 & $94 \%$ & $17 \%$ & $96 \%$ \\
\hline Siklus 2 & 95,16 & $100 \%$ & $13 \%$ & $6 \%$ \\
\hline Total Peningkatan & & & $32 \%$ & $108 \%$ \\
\hline
\end{tabular}




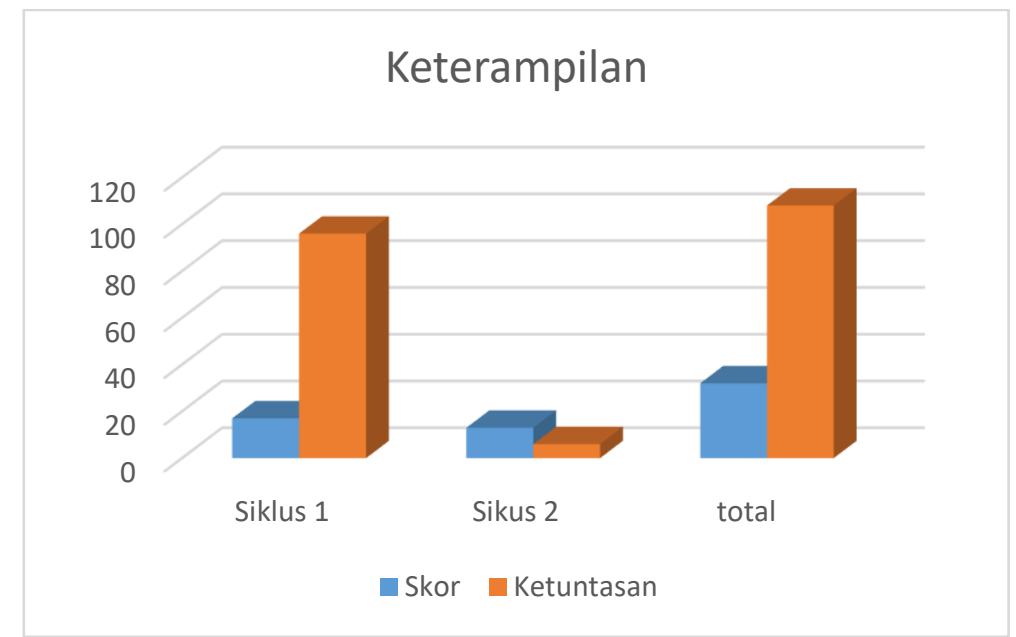

Gambar 1. Peningkatan skor keterampilan dan ketuntasan

Tabel 1. Rata-rata skor dan ketuntasan pada pengetahuan

\begin{tabular}{lcccc}
\hline & \multirow{2}{*}{ Skor } & \multirow{2}{*}{ Ketuntasan } & \multicolumn{2}{c}{ Peningkatan } \\
\cline { 4 - 5 } & & & Skor & Ketuntasan \\
\hline Data observasi & 75,20 & $64 \%$ & & \\
\hline Siklus 1 & 83,44 & $85 \%$ & $11 \%$ & $33 \%$ \\
\hline Siklus 2 & 84,70 & $97 \%$ & $2 \%$ & $14 \%$ \\
\hline Total peningkatan & & & $13 \%$ & $52 \%$ \\
\hline
\end{tabular}

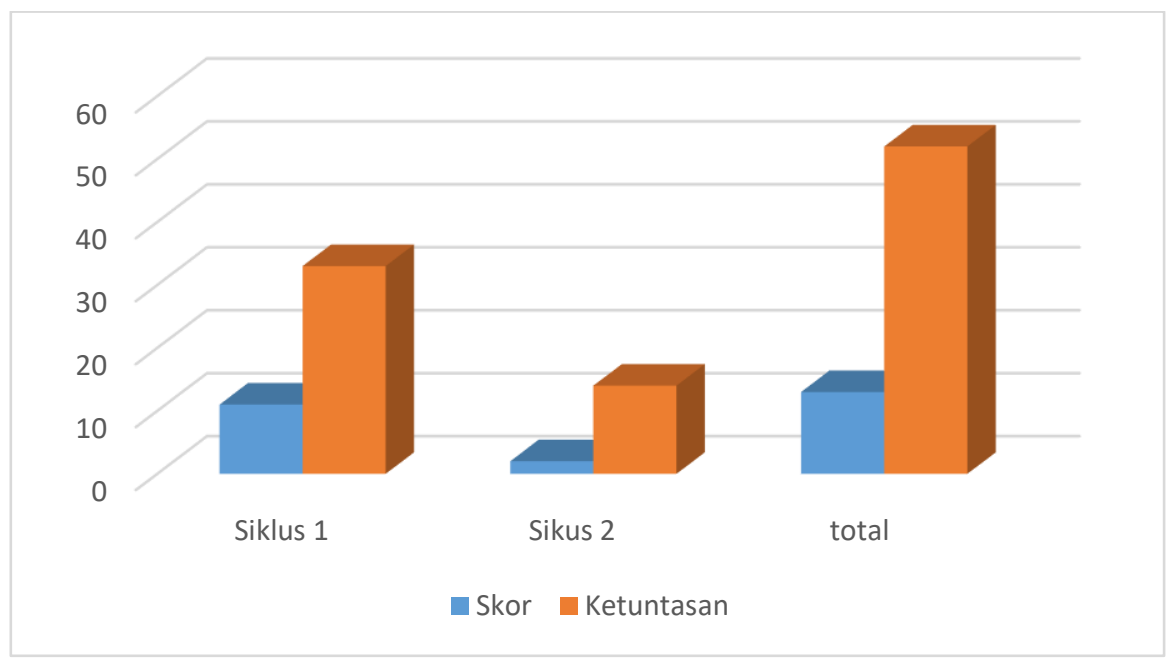

Grafik 2. Peningkatan pengetahuan

Temuan dalam pelaksanaan pembelajaran inkuiri adalah bahwa tahapan pada inkuiri mampu memfasilitasi untuk menumbuhkan rasa ingin tahu siswa, meningkatkan keaktifan siswa, menumbuhkan kolaborasi siswa, menumbuhkan tanggung jawab, menumbuhkan rasa percaya diri dan kejujuran, meningkatkan keterampilan, dan memahamkan konsep. Kegiatan praktikum dapat meningkatkan keterampilan siswa dalam menggunakan alat-alat percobaan, melakukan pengamatan, merancang percobaan, membaca data, membaca literasi, menganalisa data, membuat kesimpulan, dan menuliskan laporan. Analisis data yang dilakukan siswa membuat siswa membaca beberapa literasi. Kegiatan ini akan memperkaya pengetahuan siswa sehingga berdampak memperdalam pemahaman konsep. Pengetahuan ditambah dari presentasi yang dilakukan masing kelompok yang mempresentasikan hasil penemuan yang berbeda-beda.

\section{Pembahasan}

Hal yang dilakukan guru pada pelaksanaan pembelajaran ini adalah (1) Guru membuka pembelajaran dengan menyampaikan masalah atau fenomena di kehidupan sehari-hari (2) 
Siswa merumuskan masalah sendiri melalui fenomena dan pertanyaan yang diberikan guru (3) Siswa membuat hipotesis dari kajian bahan pustaka melalui internet (4) Siswa mendesain rancangan percobaan untuk mengumpulkan data melalui kegiatan praktikum (5) Siswa menginterpretasikan data (6) Siswa membuat kesimpulan. Guru berperan sebagai fasilitator. Dukungan guru dan kerjasama yang kuat antara guru dan siswa dalam pembelajaran inkuiri diperlukan untuk mengoptimalkan belajar siswa (Thomas, 2015).

Kelebihan ketika guru saat membuka pembelajaran dengan menyampaikan stimulus secara konstektual dengan gambar, video, benda di sekitar, atau praktik membuat siswa semangat menyimak. Siswa antusias ketika guru memliki keterampilan membuka pembelajaran (Khiroyah, 2017). Pertanyaan yang mengerucut pada masalah/ topik yang akan dibahas disampaikan guru, setelah itu siswa diminta untuk membuat pertanyaan tentang apa saja yang ingin dipelajari lebih lanjut. Pertanyaan yang dibuat siswa didiskusikan bersama kelompok untuk dipilih pertanyaan mana yang akan dicarikan solusinya. Secara tidak langsung pada tahap ini siswa memiliki keterampilan bertanya dan membuat pertanyaan.

Pertanyaan yang terpilih, merupakan rumusan masalah yang dijadikan pijakan siswa untuk mendesain praktikum. Langkah kerja disusun siswa bersama secara diskusi kelompok. Kegiatan ini membiasakan kolaborasi. Kegiatan berikutnya siswa melakukan praktikum bersama kelompok untuk mendapatkan data dari masalah yang sudah disusun. Kegiatan praktikum yang didesain sendiri oleh siswa meningkatkan semangat, keaktifan, dan kolaborasi untuk mendapatkan data. Data hasil praktikum merupakan temuan penting untuk dianalisis dan selanjutnya dirumuskan kesimpulan. Tahapan inkuiri memfasilitasi siswa untuk aktif, kreatif, dan kolaboratif. Hal senada disampaikan Meier (2000) guru harus mampu menciptakan siswa yang aktif berfikir, belajar, mencipta, dan mengekplorasi. Pembiasaan kegiatan praktikum membuat peningkatan keterampilan siswa dalam mencoba, berpikir kreatif, melakukan kegiatan ilmiah, dan membuat laporan praktikum,

Tahapan analisis pada pembelajaran inkuiri memungkinkan siswa membaca banyak literasi yang dimiliki baik dari buku atau sumber internet. Kegiatan ini berimbas pada pengetahuan siswa yang semakin beragam. Inkuiri membuat siswa dapat dipastikan untuk mencapai informasi sendiri (Sen \& Vekli, 2016). Diskusi yang dilakukan siswa dapat membuat siswa belajar mengemukakan pendapat, meningkatkan proses berpikir, kaya pengetahuan, dan mendapatkan kesepakatan baru. Inkuiri membuat siswa terlibat dalam banyak kegiatan dan proses berpikir dapat menghasilkan pengetahuan baru (Secher, 2002) \& (Joice, dkk., 2009).

Paparan kesimpulan yang dirumuskan siswa dari hasil analisis data merupakan temuan siswa yang penting. Hal ini menjadikan siswa bangga dan percaya diri dengan temuannya. Masalah yang disusun siswa berbeda-beda antar kelompok satu dengan kelompok lain sehingga menghasilkan kesimpulan yang beragam. Pengetahuan baru yang didapat siswa menjadi banyak dan beragam. Kegiatan presentasi kelas setelah tahapan inkuiri melatih keterampilan komunikasi dan rasa percaya diri siswa.

Beberapa pendapat tentang pembelajaran inkuiri dikemukakan oleh Joice, dkk. (2009) yang menyatakan bahwa pembelajaran inkuiri dapat mengembangkan disiplin intelektual dan keterampilan yang mumpuni dengan memberikan pertanyaan sehingga mendapatkan jawaban atas dasar rasa keingintahuan mereka. Amijaya (2018) menyatakan bahwa pembelajaran inkuiri dapat mendorong siswa secara aktif untuk menggali pengetahuan sendiri sehingga menjadi pribadi yang mandiri, aktif, dan terampil dalam memecahkan masalah berdasarkan informasi dan pengetahuan yang didapat.

\section{KESIMPULAN}

Keberhasilan pelaksanaan pembelajaran inkuiri didukung oleh keterampilan guru dalam mendesain pembelajaran, membuka pembelajaran, mengelola pembelajaran, dan memfasilitasi pembelajaran. Hasil menunjukkan, terdapat peningkatan keterampilan sebesar $32 \%$ untuk skor, 108\% untuk ketuntasan. Terdapat peningkatan pengetahuan sebesar13\% untuk skor, $52 \%$ untuk ketuntasan. Pembelajaran inkuiri membiasakan siswa bertanya, berpikir ilmiah, berpikir kreatif, 
berliterasi, dan berkomunikasi. Pembelajaran inkuiri mampu meningkatkan keterampilan dan pemgetahuan siswa.

\section{DAFTAR PUSTAKA}

Amijaya S.L, Ramdani A dan Merta W. (2018). Pengaruh Pembelajaran Inkuiri terbimbing Terhadap Hasil Belajar dan Kemampuan Berpikir Kritis Peserta Didik. Jurnal Pijar Mipa. Vol 2 No 02.

Dewi, D. Ayu Karmila, Sariyasa, M. (2021). Gunamantha. Pengaruh Implementasi Pembelajaran Inkuiri Berbantuan Lembar Kerja Siswa Terhadap Kemampuan Bekerjasama Dan Hasil Belajar Matematika Siswa. Jurnal Pendidikan Dasar Indonesia. Vol.5 No 1, Pebruari 2021. Hal 64-73.

Greenstein, L. (2012). Assessing $21{ }^{\text {st }}$ Century Skill: A Guide to Evaluating Mastery and Authentic Learning. California: Corwin a Sage Company.

Joice, B., Weil, M., \& Calhoun, E. (2000). Models of Teaching (6th ed.). Boston: Allyn and Bacon.

Joice, B., Weil, M., \& Calhoun, E. (2009). Models of Teaching (9th ed.). Boston: Allyn and Bacon.

Khiroyah, A. J. (2017). Pentingnya Keterampilan Guru Dalam Membuka Pelajaran. Research Report.

Meier, D. (2000). The Accelerated Learning Handbooks. New York: Mc Graw Hill.

Nurussaniah, Eka Trisianawati, Ira Nofita Sari. (2017). Pembelajaran Inkuiri untuk Meningkatkan Keterampilan Proses Sains Calon Guru Fisika. Jurnal Pendidikan Fisika Al-biruni. Vol. 6 No. 2.

Peraturan Menteri Pendidikan dan Kebudayaan Republik Indonesia 2015 Nomor 53, Penilaian Hasil Belajar Oleh Pendidik Pada Pendidikan Dasar dan Pendidikan Menengah.

Secker, V. C. (2002). Effects of Inquiry-Based Teacher Practices on Science Excellence and Equity. The Journal of Educational Research. 95 (3).

Sen, S., Yilmaz, A., Geban, O. (2015). The Effects of Process Oriented Guided Inquiry Learning Environment on Students' Self-Regulated Learning Skills. Problems of Education in the $21^{\text {st }}$ Century, $66: 54-66$.

Sen, C. \& Vekli, G. S. (2016). The Impact of Inquiry Based Instruction on Science Process Skills and Self-efficacy Perceptions of Pre-service Science Teachers at a University Level Biology Laboratory. Universal Journal of Educational Research 4(3): 603-612.

Suansah. (2015). Penerapan Pendekatan Inkuiri Untuk Meningkatkan Keterampilan Proses Siswa Pada Pembelajaran Ipa Pokok Bahasan Konduktor Dan Isolator Panas. Jurnal Profesi Pendidikan Dasar Vol. 2, No. 1, Juli 2015 : 59 - 67

Thomas, J. (2015). Resource Students' Use of Internet Inquiry Strategies in an Online Inquiry Project in Exploring Pedagogies for Diverse Learners Online. (Published online), 25 65.

Wairata, E. Penerapan Metode Belajar Inkuiri untuk Meningkatkan Hasil Belajar PKn Materi Pokok Nilai-Nilai Pancasila dalam Kerangka Praktik Penyelenggaraan Pemerintahan Negara. (2021). Journal of Education Action Research. Volume 5, Number 3, Tahun Terbit 2021, pp. 392-397. 